Portland State University

PDXScholar

Engineering and Technology Management

Faculty Publications and Presentations

Engineering and Technology Management

$9-2008$

\title{
Technology Forecasting for Wireless Communication
}

Timothy R. Anderson

Portland State University, tim.anderson@pdx.edu

Tugrul Unsal Daim

Portland State University, tugrul@etm.pdx.edu

Jisun Kim

Portland State University

Follow this and additional works at: https://pdxscholar.library.pdx.edu/etm_fac

Part of the Operations Research, Systems Engineering and Industrial Engineering Commons Let us know how access to this document benefits you.

\section{Citation Details}

Anderson, Timothy R.; Daim, Tugrul U.; and Kim, Jisun, "Technology Forecasting for Wireless Communication" (2008). Engineering and Technology Management Faculty Publications and Presentations. Paper 40. http://archives.pdx.edu/ds/psu/9649

This Article is brought to you for free and open access. It has been accepted for inclusion in Engineering and Technology Management Faculty Publications and Presentations by an authorized administrator of PDXScholar. Please contact us if we can make this document more accessible: pdxscholar@pdx.edu. 


\title{
Technology Forecasting for Wireless Communication
}

\begin{abstract}
Wireless communications technologies have undergone rapid changes over the last thirty years from analog approaches to digital-based systems. These technologies have improved on many fronts including bandwidth, range, and power requirements. Development of new telecommunications technologies is critical. It requires many years of efforts. In order to be competitive, it is critical to establish a roadmap of future technologies. This paper presents a framework to characterize, assess and forecast the wireless communication technologies. A DEA-based methodology was used for predicting the state of the art in future wireless communications technologies.
\end{abstract}

\section{Literature Review}

There are many techniques that can be used to develop technology forecasts. Linstone (1999) provides an overview of methods evolving over time. Other researchers including Ayres (1999), Martino (1999) and Porter (1999) also provide comprehensive treatments of many approaches. Technology forecasting can be done both qualitatively as well as quantitatively. Linstone (2003) and du Preez (2003) provide examples of qualitative approaches such as multiple perspectives and threat/opportunity analysis which help to dissect problems so that further analysis can be done with quantitative models. Fildes (2006) provides an excellent review of forecasting research and outlets for publications. De Gooijer et al. (2006) add to this research by focusing on time series forecasting. Meade et al.(2006) provide a similar in-depth analysis for innovation diffusion.

The Technology Futures Analysis Methods Working Group (Porter et al., 2004) provides a good review of integrating multiple methods and evolving new methods for technology forecasting. Methods used frequently include scenarios (Sager, 2003; 
Silberglitt et al., 2003; Winebrake and Creswick, 2003), Delphi (Rowe and Wright, 1999), Growth Curves (Modis, 1999; Devezas et al., 2006), Analogies (Barley, 1998) and Innovation Diffusion Forecasting (Ilonen et al., 2006). Emerging methods include use of DEA (Anderson et al., 2002; Inman et al., 2006), Evolutionary Theory (Bowonder et al., 1999), Technology Roadmaps (Phaal et al., 2004), Patent Analysis (Kayal, 1999), Bibliometric Analysis (Watts and Porter, 1997; Daim et al., 2006), and Back Propagation Network (Wang and Chien, 2006). Kumar et al. (2002) indicates the necessity of combining the forecasting model with the perceived future industry dynamics. He emphasizes that the quantitative forecasting methods such as time series and econometric modeling have become less accurate and cannot be relied upon because the industry no longer has the stable historical relationship that these models rely on. The literature suggests that including forecasts from different statistical methods generally improves accuracy when significant trends are involved. Useful information can be obtained using several sources of forecasts, adjusting for biases. Yoo and Moon (2006) suggest that instead of trying to choose the best single method, one should combine the results from different methods, which would help in reducing errors arising from faulty assumptions, biases, or mistakes in the data.

The new product development literature is relevant because the efforts to create these new technologies are relatively similar to product development and it will provide technology platforms upon which other products will be developed. There is an extensive literature on new product development but for the sake of providing a context

and linkage to this literature, we will provide a discussion of a few select papers. The importance and usefulness of this work can be demonstrated in a survey by G.M. Scott of technology management practitioners concerning new product development (Scott, 1999). Scott ranked the 24 most significant management of technology problems in new product development. The top six problems identified by practitioners were:

1. Strategic planning for technology products

2. Technology core competencies

3. Creating a conducive culture

4. New product project selection 
5. Cycle time reduction

6. Technology trends and paradigm shifts

This paper has a clear link to four of these six most important new product development problems $(1,4-6)$ faced by practitioners.

First, Moore's Law has been an important part of the long-term strategic plan of microprocessor companies as evidenced by the billions of dollars spent on manufacturing facilities for each new generation of microprocessors and the roadmaps of Sematech. Similarly, this approach can be used to develop estimates of future performance from past performance trends to assist in longer range product planning.

The connection between this work and the problem of new product project selection is clear in the domain of these types of rapidly evolving products. Using estimates of technical progress, a project can be evaluated against how it performs relative to this future level of performance. The estimate of rates of product performance change can be used to provide a clearer product performance goal early in the development stage.

As noted by Gupta and Wilemon (1990), problems with product definition were the leading cause of delayed projects. Improvements in this area will help in cycle time reduction.

The work in this paper is particularly well suited to examining technology trends and paradigm shifts. The annual technology change directly estimates measure trends. Also, it may be possible to recognize the impact of disruptive technologies such as the digital light processor technology of Texas Instruments on the computer display projector market by seeing sudden changes in the efficiency frontier or rate of change. In this way, a disruptive technology may initially appear to occupy a small niche, but as this new technology is refined, it becomes standard practice and occupies a larger portion of the frontier. This study attempts to estimate future demand for wireless technologies and evaluate the service. To this end, Technology Forecasting using Data Envelopment Analysis (TFDEA) method will be used in addition to other supplemental methods. In the 
last few years, the mobile industry has been planning on the launch of communication technologies beyond third generation (3G.)

\begin{tabular}{|c|c|c|c|}
\hline Literature & $\begin{array}{l}\text { Technology } \\
\text { Forecasting } \\
\text { Method }\end{array}$ & Description & Result \\
\hline Lee (2000) & Estimation & Future of $3 G$ & $\begin{array}{l}\text { Potential spectrum congestion and deficiency of the } \\
\text { existing 3G standard around 2007-2010; serious } \\
\text { network traffic of the existing mobile standards } \\
\text { around years 2010-2015. }\end{array}$ \\
\hline $\begin{array}{l}\text { Kumar et } \\
\text { al.(2002) }\end{array}$ & MSHARE & $\begin{array}{l}\text { A multi-component model (two- } \\
\text { phase process) }\end{array}$ & $\begin{array}{l}\text { Uses secondary data (from secondary sources) as } \\
\text { well as primary data (from the ring down } \\
\text { methodology and purchase intentions surveys). }\end{array}$ \\
\hline $\begin{array}{l}\text { Venkatesan } \\
\text { and Kumar } \\
\text { (2002) }\end{array}$ & $\begin{array}{l}\text { Genetic } \\
\text { algorithms }\end{array}$ & $\begin{array}{l}\text { Provide predictions of category } \\
\text { sales, time of peak sales and sales } \\
\text { at the peak of cell phones }\end{array}$ & $\begin{array}{l}\text { Slowdown in growth in the wireless phone market is } \\
\text { a long-term phenomenon in the seven EU countries. } \\
\text { Firms should focus on newer and useful innovations }\end{array}$ \\
\hline $\begin{array}{c}\text { Du Preez } \\
\text { and Pistorius } \\
(2003) \\
\end{array}$ & $\begin{array}{l}\text { Analysis } \\
\text { method }\end{array}$ & $\begin{array}{l}\text { Political, economic, social and } \\
\text { technological }\end{array}$ & $\begin{array}{l}\text { Support an assessment of the impacts of } \\
\text { developments on the organization. }\end{array}$ \\
\hline Frank (2004) & $\begin{array}{l}\text { Logistic } \\
\text { model }\end{array}$ & $\begin{array}{l}\text { Uses the data on wireless } \\
\text { subscribers in NMT and GSM to } \\
\text { study the diffusion of wireless } \\
\text { communications in Finland }\end{array}$ & $\begin{array}{l}\text { Economic situation has affected the relative growth } \\
\text { rate, and that the wireless network coverage has } \\
\text { affected the number of potential adopters- } \\
\text { penetration rate will be about } 91.7 \% \text { in } 2009 \text {. }\end{array}$ \\
\hline $\begin{array}{c}\text { Yoo and } \\
\text { Moon (2006) }\end{array}$ & $\begin{array}{l}\text { Contingent } \\
\text { valuation }\end{array}$ & $\begin{array}{l}\text { Assessing the future demand for } \\
\text { new technology in the early stages } \\
\text { of development or adoption }\end{array}$ & Reasonable method for future demand estimation \\
\hline
\end{tabular}

Table 1 Research focusing on Forecasting Wireless Technologies

Nunno (2003) claims that the demand for more robust mobile networks will increase even after deployment of 3G. Some characteristics of the next generation of mobile service are expected to be a greater global compatibility, a greater bandwidth and robust securities for emergent mobile-commerce applications (Nunno, 2003). Rappaport (2001) indicates in his book that the most important future process for the wireless communication will be its standardization. Table 1 provides a list of literature, the technology forecasting methods used and the results for the forecasting of future wireless technologies. 


\section{Methodology}

One of the key methods used in this report is Data Envelopment Analysis (DEA). The approach of DEA has been used in comparing telecommunication systems and countries frequently, for example, see Majumdar and Chang (1996), Sueyoshi (1998), Cooper et al. (2001), Lien and Peng (2001), and Uri (2001). In contrast, this work uses a recently developed extension of DEA called TFDEA to predict future state-of-the-art technologies. This is the first time TFDEA has been applied to wireless communication systems. TFDEA was created in 2001 as an alternative quantitative approach for technology forecasting. It has been applied to a number of industries to lend insight to managerially relevant issues. In the case of enterprise database systems (Anderson et al., 2001), it was able to empirically identify the potentially disruptive technology of open source software upon the traditional database software industry. Another application showed how Moore's Law could be extended to multiple dimensions in the case of microprocessors (Anderson et al., 2002). The latter paper, by Inman, Anderson, and Harmon, formalizes the linkage to the technology forecasting literature by rigorously comparing TFDEA to a previously published influential paper (Martino, 1993; Anderson et al., 2002) and model for technology forecasting. The TFDEA approach was found to provide both a managerially and statistically significant improvement over the previously published technology forecasting results.

TFDEA uses the concept of state of the art (SOA) in conjunction with DEA to determine historical levels of technology and determine trends in order to assess future technological characteristics. SOA is determined through analysis of products that implement a particular technology at a given point in time. The SOA is defined (Sahal, 1976) as "the state of best implemented technology as reflected by the physical and performance characteristics actually achieved during the time period in question.” TFDEA improves on previous SOA approaches by avoiding the fixed tradeoffs and central tendencies associated with regression analysis (Martino, 1992). This is done by using DEA, which is an econometric methodology for measuring relative efficiency built upon the foundations of Debreu (1951), Koopmans (1951), and Shepherd (1970). Since 
its original formulation in 1978 by Charnes et al. (1978), DEA has been widely employed for a variety of purposes in over 2000 research papers (Cooper et al., 2004). In this work we will use DEA to form a technology index of products relative to the SOA.

\section{Technology Characterization}

Different technologies and systems for cellular mobile telecommunications have been developed with the start of the communications era. There are several technical features for the classification. The first distinguishing factor among the systems is the way the signals are transmitted: analog, radio waves varying in frequency and amplitude; or digital, having a stream of discontinuous pulses that correspond to the digital bits used in computers (Rappaport, 2001; Gruber, 2005). A second important way to distinguish cellular systems according to Gruber (2005) is by the "access mechanism". The spectrum is divided into frequency bands, referred to as channels, which are then allocated to the different users. Considering the way channels are allocated, three different mechanisms can be distinguished: frequency division multiple access (FDMA), time division multiple access (TDMA) and code division multiple access (CDMA).

As a third measure, Gruber (2005) and Rappoport (2001) classify cellular mobile systems by generations, which is widely done in the communications industry. The first

generation of wireless technologies is analog systems, consisting of devices which have a military/defense origin. In the second generation, all the standards are commercial centric and they are digital in form. Later on, to meet the growing demands in the number of subscribers (increase in network capacity), rates required for high speed data transfer and multimedia applications, the third generation standards started evolving. The systems in this standard are basically a linear enhancement of 2G systems (Gruber, 2005). 


\begin{tabular}{|c|c|c|c|}
\hline \multicolumn{4}{|c|}{ Generation } \\
\hline $1 G$ & $2 G$ & $3 G$ & Beyond 3G \\
\hline Analog & Digital & Digital & Digital \\
\hline Circuit switched & Circuit switched & $\begin{array}{l}\text { Packet and circuit } \\
\text { switched }\end{array}$ & Packet switched \\
\hline $\begin{array}{l}\text { Basic voice } \\
\text { telephony }\end{array}$ & $\begin{array}{l}\text { Voice plus basic data } \\
\text { applications }\end{array}$ & $\begin{array}{l}\text { Data and multimedia } \\
\text { applications }\end{array}$ & All IP based \\
\hline Low capacity & Low data speed & Medium data rates & $\begin{array}{l}\text { More advanced multimedia } \\
\text { applications }\end{array}$ \\
\hline $\begin{array}{l}\text { Advanced mobile } \\
\text { phone service }\end{array}$ & CDMA, PDC, GSM & $\begin{array}{l}\text { WCDMA, } \\
\text { CDMA2000, } \\
\text { TD-SDMA }\end{array}$ & $\begin{array}{l}\text { OFDM, Multi Carrier } \\
\text { CDMA }\end{array}$ \\
\hline \multirow[t]{6}{*}{$\begin{array}{l}\text { Limited local ad } \\
\text { regional coverage }\end{array}$} & $\begin{array}{l}\text { Enhancements toward } \\
\text { packet-switching, } \\
\text { higher data rates }\end{array}$ & Global coverage & Global coverage \\
\hline & $\begin{array}{l}\text { Transnational and } \\
\text { global roaming }\end{array}$ & Global roaming & Global roaming \\
\hline & & & High speed data \\
\hline & & & Improved QoS \\
\hline & & & User in control \\
\hline & & & $\begin{array}{c}\text { Flexible platform of } \\
\text { complementary access } \\
\text { systems }\end{array}$ \\
\hline
\end{tabular}

Table 5 Characteristics for wireless technologies by generation (Bernard, 2003)

Fourth generation (4G) could be defined as a network based on the Internet and other applications and technologies such as Wi-Fi and WiMAX. Taking this into consideration, it can be expected that $4 \mathrm{G}$ is not going to be just one defined technology or standard, but a compatible combination of technologies and protocols to enable the highest throughput and lowest cost. Table 5 summarizes the evolution of generations of wireless technologies and their important characteristics. Important underlying technical designs included moving from an analog way of transmitting signals to digital and from circuit switched to packet switched. Each subsequent generation has been getting more complex and demanding in its evolution, but each innovation is built upon the previous technologies. The following section will review the wireless technologies and their parameters, which will lead to the table used for the TFDEA analysis. At first, a 
description will be given for the wireless technologies used, which will be followed by the parameters taken into account for analysis.

\section{First Generation Analog}

First generation (1G) wireless telephone technology is an analog cellphone standard that was introduced in the 1980s until being displaced by $2 \mathrm{G}$ digital cellphones. Table 6 gives an overview of the $1 \mathrm{G}$ technologies with their year of commercialization. Some technologies within the $1 \mathrm{G}$ are Advanced Mobile Phone Service (AMPS), Total Access Communications System (TACS) and Narrowband Analog Mobile Phone Service (NAMPS).

\begin{tabular}{|c|l|c|l|c|}
\hline Generation & \multicolumn{1}{|c|}{ Technologies } & $\begin{array}{c}\text { Multiple } \\
\text { Access } \\
\text { Method }\end{array}$ & Adoption by country & $\begin{array}{c}\text { Year of first } \\
\text { commercialization }\end{array}$ \\
\hline \hline \multirow{1}{*}{$\mathbf{1}$} & $\begin{array}{l}\text { Nordic Mobile } \\
\text { Telephone 450 (NMT- } \\
\text { 450) }\end{array}$ & FDMA & $\begin{array}{l}\text { Nordic countries, Switzerland, } \\
\text { Netherlands, Eastern Europe, } \\
\text { Russia }\end{array}$ & 1981 \\
\cline { 2 - 5 } & $\begin{array}{l}\text { Nordic Mobile } \\
\text { Telephone 900 (NMT- } \\
\text { 900) }\end{array}$ & FDMA & $\begin{array}{l}\text { Nordic countries; Switzerland, } \\
\text { Netherlands, Eastern Europe, } \\
\text { Russia }\end{array}$ & 1986 \\
\cline { 2 - 5 } $\begin{array}{l}\text { Advanced Mobile Phone } \\
\text { Service (AMPS) }\end{array}$ & FDMA & U.S., then world wide & 1983 \\
\cline { 2 - 6 } & $\begin{array}{l}\text { Total Access } \\
\text { Communications System } \\
\text { (TACS) }\end{array}$ & FDMA & UK, Italy, Spain, Austria, Ireland & 1985 \\
\cline { 2 - 6 } & $\begin{array}{l}\text { Narrowband Analog } \\
\text { Mobile Phone Service } \\
\text { (NAMPS) }\end{array}$ & U.S., Israel & 1993 \\
\hline
\end{tabular}

Table 6 First generation protocols (analog)

Analog cellular service, which imposes cost and spectral inefficiencies, is scheduled to end in 2007. Analog cellular technology has been largely replaced by digital technology.

\section{Second Generation Digital}

The second generation (2G) wireless systems were initiated mainly for voice applications and to support circuit-switched services. Table 7 gives an overview of the 
$2 \mathrm{G}$ technologies. As seen in the table, different access methods are being used for each technology such as TDMA, FDMA and CDMA.

\begin{tabular}{|c|c|c|c|c|}
\hline Generation & Technologies & $\begin{array}{l}\text { Multiple Access } \\
\text { Method }\end{array}$ & $\begin{array}{l}\text { Adoption by } \\
\text { country }\end{array}$ & $\begin{array}{c}\text { Year of first } \\
\text { commercialization }\end{array}$ \\
\hline \multirow{6}{*}{$2 G$} & $\begin{array}{l}\text { Digital AMPS (D- } \\
\text { AMPS, IS-54, TDMA) }\end{array}$ & TDMA/FDMA & $\begin{array}{l}\text { United States and } \\
\text { Canada }\end{array}$ & 1990 \\
\hline & $\begin{array}{l}\text { Personal Digital Cellular } \\
\text { (PDC) }\end{array}$ & TDMA/FDMA & Japan & 1993 \\
\hline & $\begin{array}{l}\text { Code Division Multiple } \\
\text { Access (CDMA One) }\end{array}$ & CDMA/FDMA & $\begin{array}{l}\text { North America, } \\
\text { Korea, other Asian } \\
\text { countries }\end{array}$ & 1995 \\
\hline & $\begin{array}{l}\text { Global System for } \\
\text { Mobile communications } \\
\text { (GSM) }\end{array}$ & TDMA/FDMA & $\begin{array}{l}\text { Worldwide } \\
\text { ( } 212 \text { countries) }\end{array}$ & 1992 \\
\hline & $\begin{array}{l}\text { Digital Cellular System } \\
1800 \text { (GSM 1800) }\end{array}$ & TDMA/FDMA & $\begin{array}{l}\text { Europe and Asia } \\
\text { Pacific }\end{array}$ & 1992 \\
\hline & $\begin{array}{l}\text { Integrated Digital } \\
\text { Enhanced Network } \\
\text { (iDEN) }\end{array}$ & TDMA & $\begin{array}{l}\text { North America } \\
\text { initially; Korea, } \\
\text { China, South } \\
\text { America to follow }\end{array}$ & 1994 \\
\hline \multirow{3}{*}{$2.5 \mathrm{G}$} & CVDMA2000 1XRTT & CDMA & $\begin{array}{l}\text { Korea first then } \\
\text { USA and Japan }\end{array}$ & 2001 \\
\hline & GPRS & TDMA & $\begin{array}{l}\text { An upgrade for } \\
\text { GSM networks }\end{array}$ & 2001 \\
\hline & EDGE & TDMA & $\begin{array}{l}\text { An upgrade for } \\
\text { HSCSD/GPRS } \\
\text { capable GSM } \\
\text { network }\end{array}$ & 2001 \\
\hline
\end{tabular}

Table 7 Second generation protocols (digital)

\section{Third Generation Digital}

3G systems have been designed for both voice and data. Initially, the goal was to achieve a single global standard for the 3G era (UMTS), but later on the European GSM was challenged by the CDMA technology. An overview of these systems can be seen in Table 8. 


\begin{tabular}{|c|c|c|c|c|}
\hline Generation & Technologies & $\begin{array}{c}\text { Multiple } \\
\text { Access Method }\end{array}$ & Adoption by country & $\begin{array}{c}\text { Year of first } \\
\text { commercialization }\end{array}$ \\
\hline \multirow{5}{*}{$3 G$} & $\begin{array}{l}\text { WCDMA } \\
\text { (or UMTS) }\end{array}$ & CDMA & $\begin{array}{l}\text { Korea, Japan, Europe, } \\
\text { USA and other Asian } \\
\text { Countries }\end{array}$ & 2001 \\
\hline & $\begin{array}{l}\text { CDMA2000 } \\
1 \times E V\end{array}$ & CDMA & $\begin{array}{l}\text { Same as CDMAOne plus } \\
\text { S. America, Australia, } \\
\text { India, China, Russia, and } \\
\text { Some African Countries }\end{array}$ & 2004 \\
\hline & $\begin{array}{l}\text { HSDPA } \\
\text { (TD-SCDMA) }\end{array}$ & TDMA/CDMA & China & 2007 \\
\hline & HSUPA & TDMA/CDMA & $\begin{array}{l}\text { U.S., Europe, and Japan } \\
\text { initially }\end{array}$ & 2007 \\
\hline & OFDM/OFDMA & & & \\
\hline
\end{tabular}

Table 8 Third generation protocols (digital)

Some characteristics of the $3 G$ technologies can be seen in the Appendix.

\section{Fourth Generation}

4G is short for fourth-generation. The WWRF (Wireless World Research Forum) defines 4G as "a network that operates on Internet technology, combines it with other applications and technologies such as Wi-Fi and WiMAX, and runs at speeds ranging from $100 \mathrm{Mbps}$ (in cell-phone networks) to 1 Gbps (in local Wi-Fi networks)” (Kim et al., 1999). To provide the highest throughput and lowest cost, 4G will combine the technologies and protocols accordingly.

Ohmori et al. (2000) suggest that the 4G-cellular systems should not only be highspeed but also high-capacity, with low-bit cost and the ability to support the services needed for 2010 and beyond. In order to achieve the high capacity with reasonable frequency bandwidth, Ohmori et al. (2000) expect that the cell radius of 4G-cellular systems shall be decreased from that of present cellular systems. However, current cellular radio access network (RAN) structures are not optimized for microcellular 
networks. Thus, a new revolutionary RAN structure with reduced bit cost will be an industry challenge for the coming years (Ohmori et al., 2000).

OFDM (Orthogonal Frequency Division Multiplexing) and OFDMA (Orthogonal Frequency Division Multiple Access) are candidates for the access technologies for the $4 \mathrm{G}$ in order to better allocate network resources to multiple users. 4G devices could use SDR (software-defined radio) receivers, allowing better use of available bandwidth as well as making use of multiple channels simultaneously (Ohmori et al., 2000).

Ohmori et al. (2000) suggest the following candidate future generation wireless systems: Multimedia Mobile Access (MMAC), Intelligent Transport Systems (ITSs) and High Altitude Stratospheric Platform Station Systems (HAPS) systems. More detail about these technologies can be found in the Appendix.

\section{Technology Assessment}

Recent mobile phones include various services which were not available in the past generations such as emailing, web-browsing, music and movie playing, etc. Lee (2006) suggested four categories to evaluate performance of cellular systems such as voice quality, data quality, picture/vision quality and service quality. While these four performance factors help to evaluate overall service of a cellular system from the user perspective they are largely a function of many factors beyond just the wireless technology to be forecasted. These factors include the coder/decoders, (codecs), used for sound and video, handset design, etc. For the sake of this paper, we will limit the technology forecast to the data transmission capability.

The current wireless radio communication systems consist of several kinds of wireless systems, from simple cordless phones to mobile cellular systems and personal communication systems. These different radio communication systems share some common characteristics. Arguably, the most basic differences among the technologies are 
the area covered by a base station and the speech quality. The fundamental object of wireless communication systems is to provide communication channels between a mobile radio station and a radio port or base station which connect users to the fixed network infrastructure through electromagnetic waves. Therefore, the major design factors are capacity, cost of implementation, and quality of service (Gibson, 1996).

The wireless technologies discussed in the previous sections have been developed to increase the capacity of wireless systems while keeping a certain required service quality. Therefore, the capacity of wireless communication is a very important factor for forecasting wireless communication systems.

The capacity of wireless systems is closely related to frequency usage. The frequency spectrum on which wireless communication equipment depends is a limited resource. A major problem of the radio communication system is the limitation of the available radio-frequency spectrum because of high demand with limited spectrum. Therefore, the ideal mobile system can be defined by a system operating within a limited assigned frequency band and serving an almost unlimited number of users (Lee, 2006). Key technology characteristics to improve the capacity include the channel bandwidth, information compression, variable bit-rate control, improved channel assignment algorithms, and a selection of multiple access schemes (Garg and Garg, 2001). These factors can be reflected in forecasting models directly or indirectly.

The most common measure of the capacity is spectral efficiency. A good measure of spectral efficiency helps one to estimate the capacity of a mobile communications system and allows one to set up a minimum standard as a reference of measure (Garg and Garg, 2001). Therefore, some important metrics used for measure of spectral efficiency can also provide representative performance features of a wireless technology, and hence good variables for our forecasting model. Spectral efficiency can be generalized as follows: 


$$
\text { Spectral Efficiency }=\frac{\text { Total number of channels available in the system }}{(\text { Bandwidth })(\text { Total coverage area })}
$$

Both the total number of channels and bandwidth are selected as key factors for our forecasting model. The total coverage area is excluded in this study because this factor is difficult to measure consistently across generations and is frequently specific to the particular implementation decisions of carriers. This leaves three remaining parameters affecting spectral efficiency: channel bandwidth, number of channels, and channel bit rate. The channel bit rate is included in the model since it is an important technical performance parameter even though it is not explicitly included in the spectral efficiency formula.

In addition to the three spectral efficiency related parameters which are used as major factors in the TFDEA model, other important technical parameters such as trends in transmission power, number of speech channels, and data capacity will be discussed along with their trends with respect to expected future technological progress. The detailed definitions of all parameters which are used and adopted in this study are provided in Table 9. 


\begin{tabular}{|l|l|c|}
\hline \multicolumn{1}{|c|}{ Parameter } & \multicolumn{1}{|c|}{ Definition } & Metrics \\
\hline $\begin{array}{l}\text { Channel } \\
\text { bandwidth }\end{array}$ & $\begin{array}{l}\text { Channel spacing, RF channel spacing or bandwidth per channel. } \\
\text { Example: GSM } \\
\text { Frequency band: Base station: 935-960MHz, Mobile station: 824-849MHz, } \\
\text { Bandwidth = 960-935 = 824-849=25MHz, } \\
\text { Bandwidth = channel width * number of channels }\end{array}$ & $\mathrm{kHz}$ \\
\hline $\begin{array}{l}\text { Number of } \\
\text { channels }\end{array}$ & $\begin{array}{l}\text { A channel is a communications path between two computers or devices. Most } \\
\text { commonly a channel describes a pair of radio frequencies, one to receive on } \\
\text { and one to transmit. In a digital discussion, a channel is also a communication } \\
\text { path within a data stream. Voice traffic is digitized and put within the digital } \\
\text { traffic channel. (Source: Tom Farley, "Cellular Telephone Basics", Retrieved } \\
\text { from htttp://www.privateline.com/mt_cellbasics) }\end{array}$ & Number \\
\hline $\begin{array}{l}\text { Channel bit rate } \\
\text { The channel bit rate is the channel transmission bit rate for digitally } \\
\text { rate/chip rate" }\end{array}$ & $\mathrm{kbs}$ \\
\hline $\begin{array}{l}\text { Transmission } \\
\text { power }\end{array}$ & Maximum power required to transmit signal & $\mathrm{mW}$ \\
\hline $\begin{array}{l}\text { Number of } \\
\text { speech channels }\end{array}$ & Number of users that can simultaneously access/use a channel & Count \\
\hline Data capacity & Signaling transfer speed per user & $\mathrm{kbs}$ \\
\hline
\end{tabular}

Table 9 Parameter characteristics

20 technologies and their six parameter values are used in this study as well as the year of first commercialization. Data were gathered from various sources such as books, articles, and internet websites. Since some sources are using different metrics or different concepts with the same name, validation has been done by comparing the information with multiple sources. For unclear definitions and metrics, we validated data through informal interviews with engineers in three major companies in the mobile communication industry. However, a more concrete and complete data set would aid further study. The data set used in this study is provided in Table 10. 


\begin{tabular}{|c|c|c|c|c|c|c|c|c|c|}
\hline Technology & Country adopted the technology & $\begin{array}{l}\text { Multiple } \\
\text { Access } \\
\text { Method }\end{array}$ & Year* & $\begin{array}{l}\text { Channel band } \\
\text { width (kHz) }\end{array}$ & $\begin{array}{l}\text { Transmission } \\
\text { Power ( mW) }\end{array}$ & $\begin{array}{l}\text { Humber of } \\
\text { speech channel } \\
\text { per RF channel }\end{array}$ & $\begin{array}{c}\text { Mumber of } \\
\text { Channels in } \\
\text { the } \\
\text { frequency } \\
\text { hand }\end{array}$ & $\begin{array}{c}\text { Data } \\
\text { Capacity per } \\
\text { user (kbs) }\end{array}$ & $\begin{array}{l}\text { Channel bit } \\
\text { rate (kbs) }\end{array}$ \\
\hline$\overline{\mathrm{NTT}}$ & Japan & FDMA & 1979 & 25 & - & 1 & 600 & 0.3 & 0.3 \\
\hline NMT-450 & $\begin{array}{l}\text { Nordic countries; Switzerland, } \\
\text { Netherlands, Eastern Europe, Russia }\end{array}$ & FDMA & 1981 & 25 & 15000 & 1 & 200 & 1.2 & 1.2 \\
\hline NMT-900 & $\begin{array}{l}\text { Nordic countries; Switzerland, } \\
\text { Netherlands, Eastern Europe, Russia }\end{array}$ & FDMA & 1986 & 12.5 & 3000 & 1 & 1999 & 1.2 & 1.2 \\
\hline C450 & $\begin{array}{l}\text { Germany, Austria, Portugal, South } \\
\text { Africa }\end{array}$ & & 1985 & 20 & - & 1 & 222 & 5.28 & 5.28 \\
\hline AMPS & U.S., then world wide & FDMA & 1983 & 30 & 3000 & 1 & 666 & 10 & 10 \\
\hline TACS & UK, Italy, Spain, Austria, Ireland & FDMA & 1985 & 25 & - & 1 & 1000 & 8 & 8 \\
\hline $\mathrm{CT} 2$ & Europe and Asia & FDMA & 1991 & 100 & 10 & 1 & 40 & 19.2 & 72 \\
\hline DECT & U.S., Europe & TDMAITDD & 1993 & 1728 & 250 & 12 & 10 & - & 1152 \\
\hline TDMA & United States and Canada & TDMA,FDMA & 1990 & 30 & 600 & 3 & 832 & 9.6 & 48.6 \\
\hline PDC & Japan & TDMA,FDMA & 1993 & 25 & - & 3 & 640 & 9.6 & 42 \\
\hline CDMA & $\begin{array}{l}\text { North America, Korea, Other Asian } \\
\text { countries }\end{array}$ & CDMAIFDMA & 1995 & 1250 & 600 & 15 & 20 & 14.4 & 1228.8 \\
\hline GSM & Worldwide (212 countries) & TDMA,FDMA & 1992 & 200 & 1000 & 8 & 124 & 14.4 & 270.833 \\
\hline$J D C$ & Japan & TDMA,FDMA & 1991 & 25 & - & 3 & 640 & 14 & 42 \\
\hline DCS 1800 & Europe and Asia Pacific & TDMANFDM & 1992 & 200 & 1000 & 8 & 374 & 9.6 & 270.833 \\
\hline iDEN & $\begin{array}{l}\text { North America initially; Korea, China, } \\
\text { South America to follow }\end{array}$ & TDMA & 1994 & 25 & - & 6 & 600 & 9.6 & 64 \\
\hline cdma2000 & Korea first then USA and Japan & CDMA & 2001 & 1250 & - & 30 & 64 & 153 & 1228.8 \\
\hline GPRS & An upgrade for GSM networks & TDMA & 2001 & 200 & - & - & 124 & 128 & 270.833 \\
\hline EDGE & $\begin{array}{l}\text { An upgrade for HSCSDIGPRS capable } \\
\text { GSM network }\end{array}$ & TDMA & 2001 & 200 & - & - & 195 & 384 & 812.5 \\
\hline WCDMA & $\begin{array}{l}\text { Korea, Japan, Europe, USA and other } \\
\text { Asia }\end{array}$ & CDMA & 2001 & 5000 & 2000 & 196 & 12 & 384 & 5760 \\
\hline TD-CDMA & & & 2000 & 5000 & - & - & 4 & 384 & 3300 \\
\hline
\end{tabular}

* The first commercialized year is used.

Table 10 Data set used in this study (Boucher, 1992; Hammuda, 1995; Garg and Wilkes, 1996; Gibson, 1996; Gruber, 2005; Lee, 2006) 


\section{Technology Forecasting}

This analysis is based on an extension of spectral efficiency. We examined the changing bandwidth requirements and total data capacity for 20 telecommunications protocols developed between 1979 and 2001. The data is summarized in the following table.

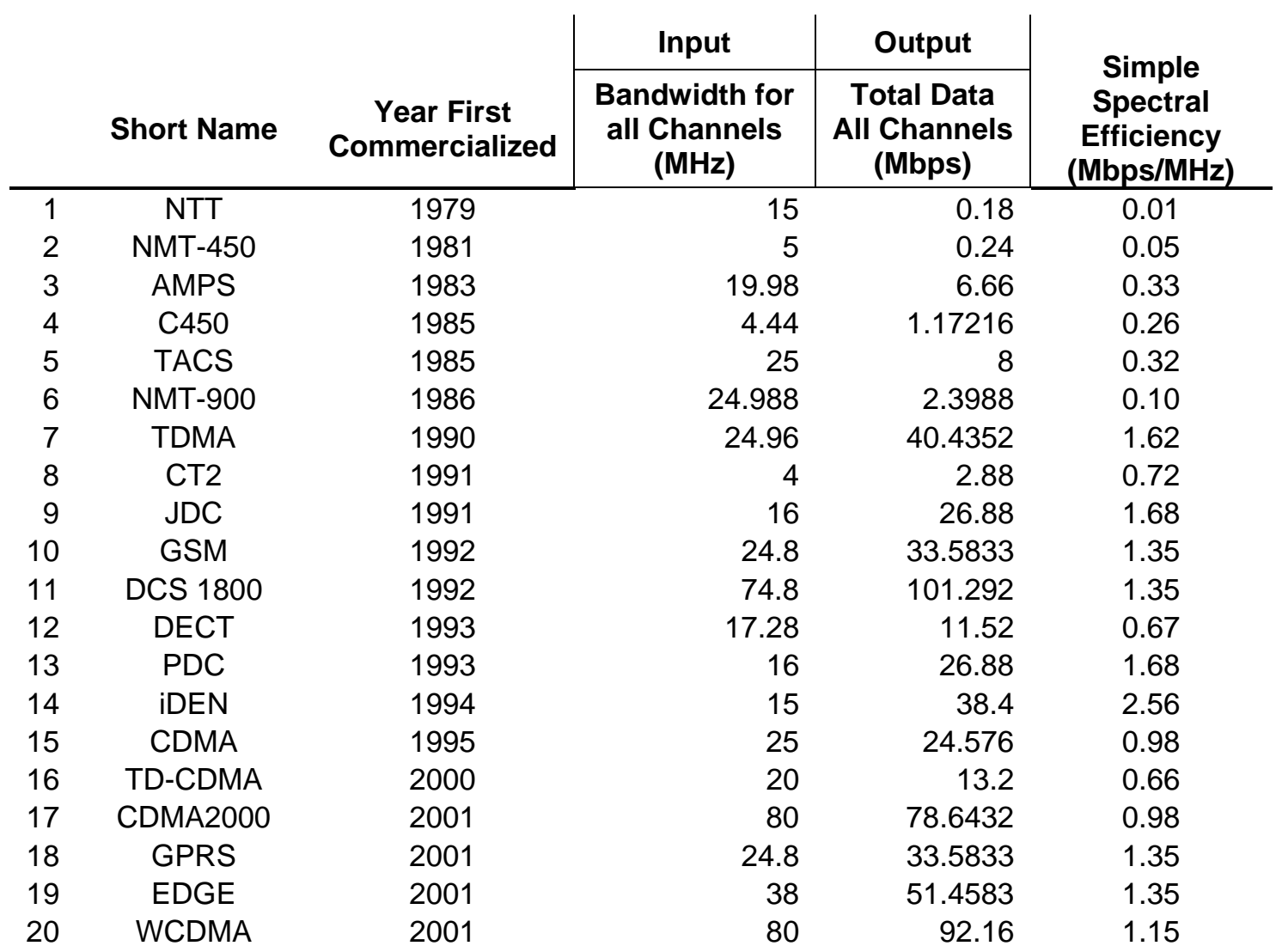

Table 11 Data used for TFDEA and the Simple Spectral Efficiency score

As discussed earlier, a variety of trends can be observed in the data including increased overall bandwidth for telecommunications protocols and increased total data capacity. Over time, increasing simple spectral efficiency is also apparent and iDEN has the highest spectral efficiency, which is consistent with the literature (Geiger et al., 1997; Hansen, 1998; Garber, 2002). 
Next we applied TFDEA to this data set. The TFDEA approach allows for multiple inputs and multiple outputs, but in this application, we found the best model to be a straightforward one input, one output model. We used as an input the total bandwidth for all channels (measured in Megahertz) and as an output the total data for all channels as measured in megabits per second. TFDEA allows for different returns to scale assumptions. In this study, we used variable returns to scale, although increasing, decreasing, or constant returns to scale could also be used.

The TFDEA approach is mathematically summarized in equations (1) through (11). The analytical core of TFDEA is an econometric technique called Data Envelopment Analysis (DEA) developed Charnes et al. (1978). We used a simplified TFDEA approach relative to some earlier work by foregoing a variable frontier time denoted as $t_{\text {effective }}$ (or $t_{\text {eff }}$ ) in Inman et al. (2006). A detailed explanation and compelling validation of TFDEA in comparison to other technology forecasting approaches can also be found in Inman et al. (2006). Conceptually, TFDEA calls for testing each technology, $k$, at each time period, $t_{f}$, against all technologies commercialized up to that time. Briefly, $x_{i, k}$ represents the $i$ 'th input and $y_{r, k}$ represents the $r$ 'th output of technology $k$. In the current study with its one input and one output model, this results in $m=s=1$. The variables for the linear program underlying DEA are $\lambda_{j, k}$ and $\phi_{k}^{t_{f}}$. The variable $\phi_{k}^{t_{f}}$ also serves as the objective function and represents the amount of additional output which should be achievable by technology $k$ at time period $t_{f}$ if it were state of the art at that time. The variables, $\lambda_{j, k}$, describe how much of technology $j$ is used in setting a target of performance for technology $k$. 


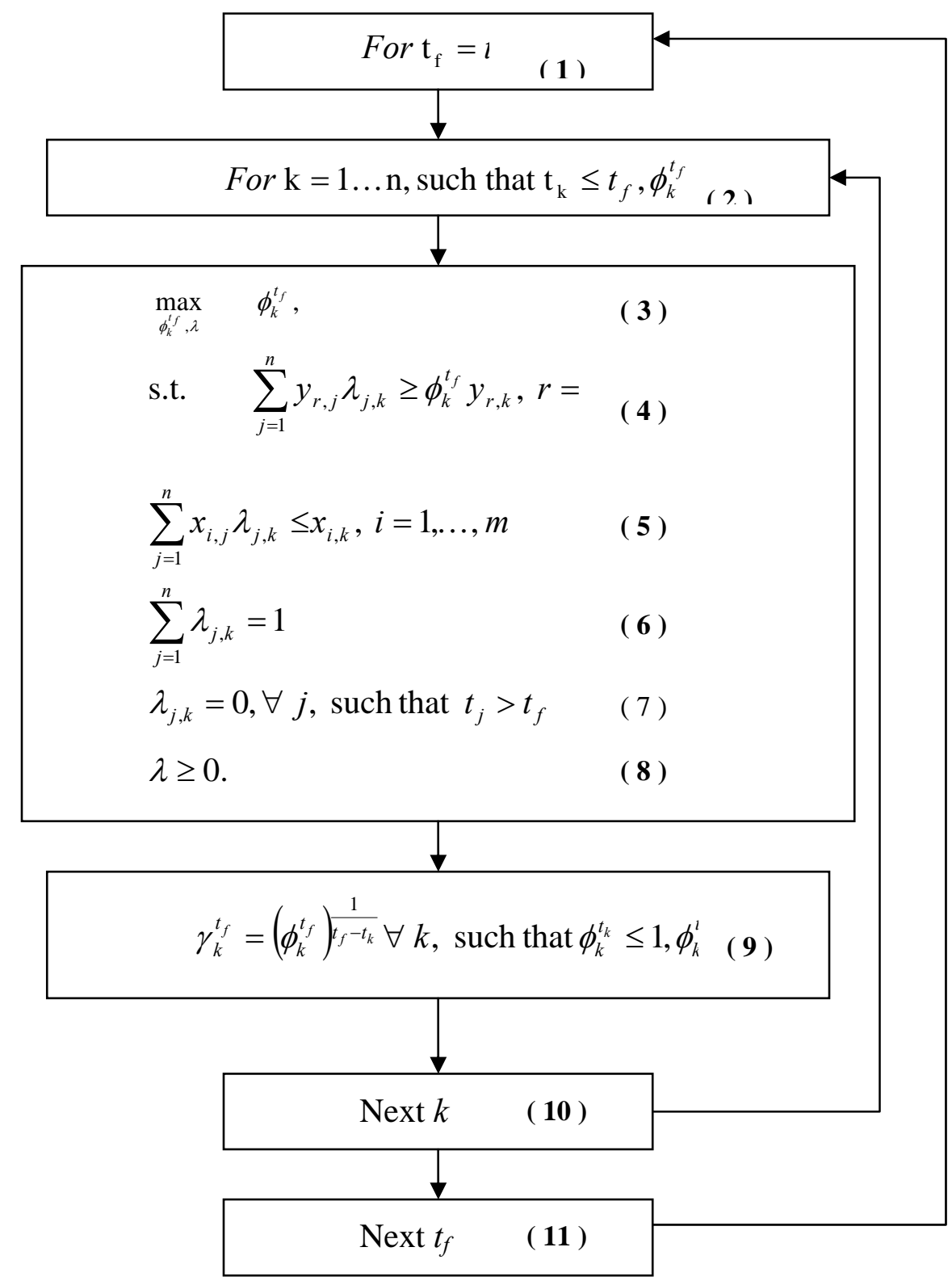

The first result is a comparison of each technology to all technologies available at that time and earlier. In these results as noted in the following table, technologies with a score of 1.0 are considered efficient at time of first commercialization. Conversely, scores larger than one indicate the amount by which the output (total data capacity across all channels) should be increased relative to its input in order to be SoA in the year of its release compared to other available technologies. 


\begin{tabular}{|c|c|c|c|c|c|c|}
\hline k & $\begin{array}{l}\text { Short } \\
\text { Name }\end{array}$ & $\begin{array}{l}\text { Year } \\
\text { First } \\
\text { Comer- } \\
\text { cialized }\end{array}$ & $\begin{array}{l}\text { Bandwidth } \\
\text { for all } \\
\text { Channels } \\
\text { (MHz) }\end{array}$ & $\begin{array}{l}\text { Total Data } \\
\text { All } \\
\text { Channels } \\
\text { (Mbps) }\end{array}$ & $\begin{array}{c}\text { Simple Spectral } \\
\text { Efficiency } \\
\text { (Mbps/MHz) }\end{array}$ & $\begin{array}{c}\text { Efficiency } \\
\text { at Time of } \\
\text { Release } \\
\gamma_{k}^{2001}\end{array}$ \\
\hline 1 & NTT & 1979 & 15 & 0.18 & 0.01 & 1 \\
\hline 2 & NMT-450 & 1981 & 5 & 0.24 & 0.05 & 1 \\
\hline 3 & AMPS & 1983 & 19.98 & 6.66 & 0.33 & 1 \\
\hline 4 & C450 & 1985 & 4.44 & 1.17216 & 0.26 & 1 \\
\hline 5 & TACS & 1985 & 25 & 8 & 0.32 & 1 \\
\hline 6 & NMT-900 & 1986 & 24.988 & 2.3988 & 0.10 & 3.33361 \\
\hline 7 & TDMA & 1990 & 24.96 & 40.4352 & 1.62 & 1 \\
\hline 8 & СТ2 & 1991 & 4 & 2.88 & 0.72 & 1 \\
\hline 9 & JDC & 1991 & 16 & 26.88 & 1.68 & 1 \\
\hline 10 & GSM & 1992 & 24.8 & 33.5833 & 1.35 & 1.19682 \\
\hline 11 & DCS 1800 & 1992 & 74.8 & 101.292 & 1.35 & 1 \\
\hline 12 & DECT & 1993 & 17.28 & 11.52 & 0.67 & 2.50143 \\
\hline 13 & PDC & 1993 & 16 & 26.88 & 1.68 & 1 \\
\hline 14 & iDEN & 1994 & 15 & 38.4 & 2.56 & 1 \\
\hline 15 & CDMA & 1995 & 25 & 24.576 & 0.98 & 1.99044 \\
\hline 16 & TD-CDMA & 2000 & 20 & 13.2 & 0.66 & 3.30746 \\
\hline 17 & CDMA2000 & 2001 & 80 & 78.6432 & 0.98 & 1.28799 \\
\hline 18 & GPRS & 2001 & 24.8 & 33.5833 & 1.35 & 1.45032 \\
\hline 19 & EDGE & 2001 & 38 & 51.4583 & 1.35 & 1.21631 \\
\hline 20 & WCDMA & 2001 & 80 & 92.16 & 1.15 & 1.09908 \\
\hline
\end{tabular}

Table 12 Data used for TFDEA and the Simple Spectral Efficiency score 


\begin{tabular}{|c|c|c|c|c|c|c|c|c|c|c|c|c|}
\hline \multirow[b]{2}{*}{$\mathbf{k}$} & \multirow{2}{*}{ Short Name } & \multirow{2}{*}{$\begin{array}{c}\text { Year } \\
\text { First } \\
\text { Comm- } \\
\text { ercialized } \\
t_{k}\end{array}$} & \multirow{2}{*}{$\begin{array}{c}\text { Efficiency } \\
\text { at Time of } \\
\text { Release } \\
\phi_{k}^{t_{k}}\end{array}$} & \multicolumn{9}{|c|}{$\phi_{k}^{t_{f}}$} \\
\hline & & & & 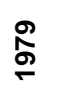 & 总 & $\begin{array}{l}\mathscr{0} \\
\text { g్ }\end{array}$ & 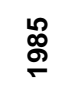 & ஓి & ๙ั & ஓু & 용 & 엉 \\
\hline 1 & NTT & 1979 & 1 & 1 & 1.33 & 25.1 & 27.2 & 119 & 138 & 213 & 213 & 213 \\
\hline 2 & NMT-450 & 1981 & 1 & & 1 & 1 & 5.71 & 9.35 & 20.3 & 25.5 & 25.5 & 25.5 \\
\hline 3 & AMPS & 1983 & 1 & & & 1 & 1 & 4.64 & 4.94 & 6.55 & 6.55 & 6.55 \\
\hline 4 & C450 & 1985 & 1 & & & & 1 & 1 & 3.21 & 3.67 & 3.67 & 3.67 \\
\hline 5 & TACS & 1985 & 1 & & & & 1 & 5.05 & 5.06 & 6.11 & 6.11 & 6.11 \\
\hline 6 & NMT-900 & 1986 & 3.33361 & & & & & 16.9 & 16.9 & 20.4 & 20.4 & 20.4 \\
\hline 7 & TDMA & 1990 & 1 & & & & & 1 & 1 & 1.21 & 1.21 & 1.21 \\
\hline 8 & СТ2 & 1991 & 1 & & & & & & 1 & 1 & 1 & 1 \\
\hline 9 & JDC & 1991 & 1 & & & & & & 1 & 1.47 & 1.47 & 1.47 \\
\hline 10 & GSM & 1992 & 1.19682 & & & & & & 1.2 & 1.45 & 1.45 & 1.45 \\
\hline 11 & DCS 1800 & 1992 & 1 & & & & & & 1 & 1 & 1 & 1 \\
\hline 12 & DECT & 1993 & 2.50143 & & & & & & & 3.54 & 3.54 & 3.54 \\
\hline 13 & PDC & 1993 & 1 & & & & & & & 1.47 & 1.47 & 1.47 \\
\hline 14 & iDEN & 1994 & 1 & & & & & & & 1 & 1 & 1 \\
\hline 15 & CDMA & 1995 & 1.99044 & & & & & & & & 1.99 & 1.99 \\
\hline 16 & TD-CDMA & 2000 & 3.30746 & & & & & & & & & 3.31 \\
\hline 17 & CDMA2000 & 2001 & 1.28799 & & & & & & & & & 1.29 \\
\hline 18 & GPRS & 2001 & 1.45032 & & & & & & & & & 1.45 \\
\hline 19 & EDGE & 2001 & 1.21631 & & & & & & & & & 1.22 \\
\hline 20 & WCDMA & 2001 & 1.09908 & & & & & & & & & 1.10 \\
\hline
\end{tabular}

Table 13 Changing efficiency scores over time

A number of interesting conclusions can be drawn from the preceding table. As we would expect, first technologies can be rapidly superseded by new technologies. While NTT's wireless protocol was SoA in 1979, as demonstrated by the efficiency score of one, it was immediately surpassed when the next technology was commercialized. To be SoA in 1981, it needed to achieve 33\% more output (data capacity in megabits per second) for the same input (bandwidth in $\mathrm{MHz}$ ) and by 1994, a SoA telecommunications protocol would achieve 212 times more output using the same bandwidth demands as NTT.

In contrast, some technologies continue to be deemed SoA for a range of years in terms of our spectrum efficiency. For example, CT2 was efficient at the time of first 
commercialization in 1991 and continued to be efficient relative to other technologies through 2001.

The aforementioned measurements of how the technology is surpassed over time can be used to estimate a rate of technology change. For this we will use the year 2001 values of technology being surpassed but which had been SoA at time of release to calculate the amount by which wireless technology had progressed. In other words, what annual rate of change would be needed to explain the amount by which a previously SoA technology had been superceded by 2001. The following table lists the eight technologies which were state of the art (efficient) at time of release but were surpassed by future technologies. The average annual rate of change was 1.109 , indicating that output data capacity for wireless technology protocols increased by about $10.9 \%$ per year for any fixed level of input (bandwidth).

\begin{tabular}{rccccc}
$\boldsymbol{k}$ & $\begin{array}{c}\text { Short } \\
\text { Name }\end{array}$ & $\begin{array}{c}\text { Year first } \\
\text { Commercialized } \\
\boldsymbol{t}_{\boldsymbol{k}}\end{array}$ & $\begin{array}{c}\text { Efficiency at } \\
\text { Time of } \\
\text { Release } \\
\boldsymbol{\phi}_{k}\end{array}$ & $\begin{array}{c}\text { Efficiency } \\
\text { Relative to } \\
\text { 2001 State of } \\
\text { the Art } \\
\phi_{k}^{2001}\end{array}$ & $\begin{array}{c}\text { Annual Rate } \\
\text { of Change }\end{array}$ \\
\hline 1 & NTT & 1979 & 1 & 213 & \\
2 & NMT-450 & 1981 & 1 & 25.5 & 1.27605 \\
3 & AMPS & 1983 & 1 & 6.55 & 1.17568 \\
4 & C450 & 1985 & 1 & 3.67 & 1.11008 \\
5 & TACS & 1985 & 1 & 6.11 & 1.08464 \\
7 & TDMA & 1990 & 1 & 1.21 & 1.11982 \\
9 & JDC & 1991 & 1 & 1.47 & 1.01738 \\
13 & PDC & 1993 & 1 & 1.47 & 1.03912 \\
\hline & & & & Average & 1.10899
\end{tabular}

Table 14 Technological rate of change

The rate of change value can then be used to estimate future levels of technology performance for SoA technologies. The following table takes the year 2001 technologies and first multiplies their outputs (data capacity) by the efficiency scores to develop an 
efficient projection and then multiplies that by the rate of change raised to the power corresponding to the forecast year.

\begin{tabular}{|c|c|c|c|c|c|c|c|c|}
\hline \multirow[b]{2}{*}{$\mathrm{k}$} & & \multirow{2}{*}{$\begin{array}{l}\text { BW All } \\
\text { channels } \\
\text { (MHz) }\end{array}$} & \multirow{2}{*}{$\begin{array}{l}\text { Total } \\
\text { Data } \\
\text { Capacity } \\
\text { (Mbps) }\end{array}$} & \multirow{2}{*}{$\begin{array}{c}\text { Efficiency } \\
\text { Relative to } 2001 \\
\text { State of the Art } \\
\phi_{k}^{2001}\end{array}$} & \multirow{2}{*}{$\begin{array}{c}2001 \\
\text { Target } \\
\text { Data } \\
\text { Capacity }\end{array}$} & \multicolumn{3}{|c|}{$\begin{array}{c}\text { Future Forecasts of Total Data } \\
\text { Capacity (Mbps) }\end{array}$} \\
\hline & & & & & & 2006 & 2011 & 2015 \\
\hline 17 & CDMA2000 & 80.00 & 78.64 & 1.29 & 101.29 & 169.90 & 284.99 & 431.06 \\
\hline 18 & GPRS & 24.80 & 33.58 & 1.45 & 48.71 & 81.70 & 137.04 & 207.28 \\
\hline 19 & EDGE & 38.00 & 51.46 & 1.22 & 62.59 & 104.99 & 176.10 & 266.36 \\
\hline 20 & WCDMA & 80.00 & 92.16 & 1.10 & 101.29 & 169.90 & 284.99 & 431.06 \\
\hline
\end{tabular}

Table 15 Forecasts of future state of the art performance

This forecast predicts that in order for successors to the CDMA-based technologies (CDMA 2000 and WCDMA) to be technologically state of the art in 2011, they will need to support a data transmission capacity of 285 Mbps given the same 80 MHz bandwidth.

HSDPA is the first evolution of WCDMA released in 2006 (Rysavy, 2006). The total data capacity within the broadband of $1920-1980 \mathrm{MHz}$ is 138.24Mbps (Derksen et al., 2006). In other words, the data capacity for $60 \mathrm{MHz}$ of bandwidth will be 138.24Mbps. Our analysis has predictions for bandwidths of 38 and $80 \mathrm{MHz}$. They are 104.99 and 169.90 Mbps respectively for 2006. A simple calculation would show that our analysis is predicting $138.99 \mathrm{Mbps}$. The prediction is extremely close to the actual in 2006.

\section{Discussion}

There are several implications of the research findings for both theory and practice. From a theoretical perspective, the paper expands the use of DEA in technology forecasting. The findings are also important for practice. TFDEA is application of DEA 
to technology forecasting and was developed at Portland State University. The methodology so far has been applied to microprocessors, fighter jets, enterprise data systems and USB drives. It is the first time it is applied to wireless communication technologies. As the methodology requires the identification of a product function, it also defines the critical input and output elements that makes a wireless communication technology efficient. The function defined provides a relationship among key technical specifications that the service providers or manufacturers have control over and the customer preferences. In this way the methodology provides quantification and prediction functions for the research in quality function deployment or house of quality. Another aspect of using TFDEA on wireless communication technologies is the service perspective. This is the first time TFDEA has been used for a service innovation and it proved useful in this case as well.

Our results will provide further research direction for technology forecasting. Many models in the literature focused on one parameter at a time. Our model provides a multi-dimensional view of performance. We believe the process utilized in this research can be generalized so that researchers can initially identify the major components of the technology under investigation. In the paper, this was accomplished by defining spectral efficiency. One can take this to a level where spectral efficiency equivalents are defined for different major group of technologies, thus defining a system of technology evaluation and forecasting that can be used for almost any application. One other expansion of our model would be to monitor different technologies over time and try to capture changes in the efficiency model which may be good indicator for the presence of disruptive technologies. Continuous monitoring may enable us to predict the arrival of disruptive technologies.

Product development is one area that would benefit from this type of analysis. A range of performance parameters forecasted into the future will help validate design targets for products driven by new technologies. Typical R\&D projects have high uncertainty in the beginning. The uncertainty ranges from design targets to expected performance. Although we may not necessarily help with expected physical performance, 
we may help reduce the uncertainty in the targeted range. The process can also be expanded to include other elements such as resources, expenses and other constraints to help us to assess whether or not we are getting more or less efficient in developing products. The phases where this will be most efficient would be the early phases. These are sometimes referred to as fuzzy front end of product development, where there is uncertainty about customer requirements and technology limits. So our approach can be a powerful tool to help reduce the fuzziness of the front end of product development.

Although the methodology provides good insight, decision makers should use this as a reference and combine it with other analyses being made, such as market and technology analyses. Recent wireless technologies have achieved similar spectral efficiency levels in the physical layer reaching to the theoretical limits with a focus on improving system performance (Rysavy, 2006). Therefore, comparing technologies of the same generation with a single measurement of spectral efficiency may not provide enough insight into when a new generation of technology will actually be adopted in a future market. While the methodology used in this paper provides how a specific technology will evolve over time based on a linear improvement in system performance, it will be vital to keep monitoring the market dynamics. For example, carriers may agree to choose to fully utilize the current infrastructure before they invest into a new one. These companies will most probably consider the adoption of any new technology to understand the optimal time to deploy the new technology. This type of market information could add value to the forecast for the wireless technologies. For this purpose additional analyses are recommended and they may include cost/benefit analysis and plotting growth curves of current and future generations. 


\section{Conclusions}

The wireless technology industry has been rapidly evolving with dramatic technology changes. As the technology has advanced, development costs and times have increased, resulting in a greater need for insights regarding what the future holds. There has been a variety of both technology and market forecasts applied to the wireless technology.

This study examined past studies and applied a comprehensive approach including 3 steps, which are technology characterization, assessment and forecasting.

Step 1 included a review of wireless technologies. Through this step, we identified the path of technology evolution. This helped us to identify which technologies and standards we were going to use for our analysis.

Step 2 included a more detailed review of technical parameters that we were trying to assess and forecast. This phase resulted in a model and a set of variables to be used in our analysis. In this step we also conducted a forecast of the variables in the model independent of each other.

Step 3 utilized a new approach, TFDEA for the first time in the wireless technology industry. It was found that a forecast of future performance could be developed and historical developments tracked. Future work could extend this model to incorporate additional inputs and outputs as well as additional wireless technology protocols.

The three step process can easily be applied to other types of technologies, thus creating further technology forecasting opportunities. 
The paper also included a limited validation where the forecasted performance was compared to the actual data. HSDPA, which is an advanced version of WCDMA released in 2006, has a total data capacity of $138.24 \mathrm{Mbps}$. Our model, built on historical data up until 2001, had indicated a data capacity of 138.99 Mbps for 2006.

Finally this paper provides a group of future expansion of this research explained in the discussion part and summarized below:

1. Developing further TFDEA models of other service innovations

2. Developing "spectral efficiency" equivalent for other technologies and related applications.

3. Developing monitoring systems for predicting the arrival of disruptive technologies.

4. Incorporating the approach into the front end of product development process to reduce the uncertainty. Case studies measuring improvements would be very useful.

\section{References}

Anderson, T., R. Fare, et al., 2002, "Further examination of Moore's law with data envelopment analysis." Technological Forecasting and Social Change 69(5), 465-477.

Anderson, T. R., R. Fare, et al., 2002, "Further examination of Moore's law with data envelopment analysis." Technological Forecasting and Social Change 69(5), 465-477.

Anderson, T. R., K. Hollingsworth, et al., 2001, Assessing the rate of change in the enterprise database system market over time using DEA. Technology Management in the Knowledge Era. D. F. Kocaoglu and T. R. Anderson. Portland, PICMET, 384-390. 
Ayres, R. U., 1999, "What Have We Learned?" Technological Forecasting and Social Change 62(1), 9-12.

Barley, S. R., 1998, "What can we learn from the history of technology." Journal of Engineering and Technology Management 15, 237-255.

Bernard, B., 2003, Systems beyond IMT-2000, Geneva: ITU-T Workshop on Next Generation Networks

Boretos, G. P., 2007, "The future of the mobile phone business." Technological Forecasting and Social Change 74(3), 331-340.

Boucher, N. J., 1992, Cellular radio handbook : a reference for cellular system operation. Denver, Colo., Quantum Pub.

Bowonder, B., T. Miyake, et al., 1999, "Predicting the Future: Lessons from Evolutionary Theory." Technological Forecasting and Social Change 62(1), 51-62.

Charnes, A., W. W. Cooper, et al., 1978, "Measuring the efficiency of decision making units." European Journal of Operational Research 2(6), 429-44.

Cooper, W. W., P. Kyung Sam, et al., 2001, "An illustrative application of idea (imprecise data envelopment analysis) to a Korean mobile telecommunication company." Operations Research 49(6), 807-820.

Cooper, W. W., L. M. Seiford, et al., Eds., 2004, Handbook on Data Envelopment Analysis. International Series in Operations Research \& Management Science. Dordrecht, Springer.

Daim, T. U., G. Rueda, et al., 2006, "Forecasting emerging technologies: Use of bibliometrics and patent analysis." Technological Forecasting and Social Change 73(8), 981-1012.

De Gooijer, J. G. and R. J. Hyndman, 2006, "25 years of time series forecasting." International Journal of Forecasting 22(3), 443-473.

Debreu, G., 1951, "The coefficient of resource utilization." Econometrica 19(3), 273-292.

Derksen, J., R. Jansen, et al., 2006, "HSDPA performance and evolution." Ericsson Review 3. 
Devezas, T. C., H. A. Linstone, et al., 2006, "The growth dynamics of the Internet and the long wave theory." Technological Forecasting and Social Change, 913-935.

du Preez, G. T. and C. W. I. Pistorius, 2003, "Analyzing technological threats and opportunities in wireless data services." Technological Forecasting and Social Change 70(1), 1-20.

Fildes, R., 2006, "The forecasting journals and their contribution to forecasting research: Citation analysis and expert opinion." International Journal of Forecasting 22(3), 415432.

Frank, L. D., 2004, "An analysis of the effect of the economic situation on modeling and forecasting the diffusion of wireless communications in Finland." Technological Forecasting and Social Change 71(4), 391-403.

Garber, L., 2002, "Will 3 G really be the next big wireless technology." Computer 35(1), 26-32.

Garg, V. K. and V. K. Garg, 2001, Introduction to wireless and personal communications. Piscataway, NJ, Institute of Electrical and Electronics Engineers.

Garg, V. K. and J. E. Wilkes, 1996, Wireless and personal communications systems. Upper Saddle River, NJ, Prentice Hall PTR.

Geiger, R. L., J. D. Solomon, et al., 1997, "Wireless network extension using mobile IP." IEEE Micro 17(6), 63-68.

Gibson, J. D., 1996, The mobile communications handbook. Boca Raton, IEEE Press.

Gruber, H., 2005, The Economics of Mobile Telecommunications. Cambridge ; New York, Cambridge University Press.

Gupta, A. and D. Wilemon, 1990, "Accelerating the development of technology-based new products." California Management Review 32(2), 23-33.

Hammuda, H., 1995, Spectral efficiency of digital cellular mobile radio systems.

Hansen, K., 1998, Wireless communications devices and technology: Future directions, Baltimore, MD, USA, IEEE, Piscataway, NJ, USA. 
Ilonen, J., K. Joni-Kristian, et al., 2006, "Toward automatic forecasts for diffusion of innovations." Technological Forecasting and Social Change 73(2), 182-198.

Inman, O. L., T. R. Anderson, et al., 2006, "Predicting U.S. jet fighter aircraft introductions from 1944 to 1982: A dogfight between regression and TFDEA." Technological Forecasting and Social Change.

Islam, T. and N. Meade, 1997, "The diffusion of successive generations of a technology: A more general model." Technological Forecasting and Social Change 56(1), 49-60.

Kayal, A., 1999, "Measuring the Pace of Technological Progress: Implications for Technological Forecasting." Technological Forecasting and Social Change 60(3), 237245.

Kim, Y. B., S. Y. Seo, et al., 1999, A substitution and diffusion model with exogenous impact: forecasting of IMT-2000 subscribers in Korea.

Koopmans, T. C., 1951, An analysis of production as an efficient combination of activites. Activity Analysis of Production and Allocation. T. C. Koopmans. New York, John Wiley and Sons, Inc. 13.

Kumar, V., A. Nagpal, et al., 2002, "Forecasting category sales and market share for wireless telephone subscribers: A combined approach." The International Journal of Forecasting 18, 583-603.

Lee, J., 2000, Research and development for system beyond IMT-2000 in Korea Korea Telecom

Lee, W. C. Y., 2006, Wireless and cellular telecommunications, McGraw-Hill.

Lien, D. and Y. Peng, 2001, "Competition and production efficiency:

Telecommunications in OECD countries." Information Economics and Policy 13(1), 5176.

Linstone, H. A., 1999, "Tfsc: 1969-1999." Technological Forecasting and Social Change 62(1), 1-8.

Linstone, H. A., 2003, "The 21st century: Everyman as Faust - Technology, Terrorism, and the Multiple Perspective Approach." Technological Forecasting and Social Change 70(3), 283-296. 
Majumdar, S. K., 1995, "Divestiture and productive efficiency in the U.S. telecommunications industry." European Transactions on Telecommunications 6(4), 385395.

Majumdar, S. K., 1995, "X-efficiency in emerging competitive markets: The case of U.S. telecommunications." Journal of Economic Behavior \& Organization 26(1), 129-144.

Majumdar, S. K., 1998, "On the utilization of resources: Perspectives from the U.S. telecommunications industry." Strategic Management Journal 19(9), 809-831.

Majumdar, S. K. and H. Chang, 1996, "Scale efficiencies in US telecommunications: An empirical investigation." Managerial \& Decision Economics 17(3), 303-318.

Martino, J. P., 1992, Technological Forecasting for Decision Making. New York, Mc Graw Hill.

Martino, J. P., 1993, "A comparison of two composite measures of technology " Technological Forecasting and Social Change 44 (2), 147-159.

Martino, J. P., 1999, "Thirty years of change and stability." Technological Forecasting and Social Change 62(1), 13-18.

Meade, N. and T. Islam, 2006, "Modelling and forecasting the diffusion of innovation \#8211 A 25-year review." International Journal of Forecasting 22(3), 519-545.

Modis, T., 1999, "Technological forecasting at the stock market." Technological Forecasting and Social Change 62(3), 173-202.

Nunno, R., 2003, Migration to 3G technology standards:Europe, Japan, South Korea, and the U.S., International Bureau Federal Communications Commission

Ohmori, S., Y. Yamao, et al., 2000, "The future generationns of mobile communications based on broadband access technologies." IEEE Communications Magazine 38(12), 134142.

Phaal, R., C. J. P. Farrukh, et al., 2004, "Technology roadmapping-A planning framework for evolution and revolution." Technological Forecasting and Social Change 71(1), 5-26. 
Porter, A. L., 1999, "Tech Forecasting: An Empirical Perspective." Technological Forecasting and Social Change 62(1), 19-28.

Porter, A. L., B. Ashton, et al., 2004, "Technology futures analysis: Toward integration of the field and new methods." Technological Forecasting and Social Change 71(3), 287303.

Rappaport, T., 2001, Wireless Communications: Principles and Practice, Prentice Hall.

Rowe, G. and G. Wright, 1999, "The Delphi technique as a forecasting tool: issues and analysis." International Journal of Forecasting 15(4), 353-375.

Rysavy, P., 2006, Mobile Broadband EDGE, HSPA \& LTE, ITU

Sager, B., 2003, "Scenarios on the future of Biotechnology." Technological Forecasting and Social Change 70, 109-129.

Sahal, D., 1976, "The Generalized Distance Measures of Technology." Technological Forecasting and Social Change 9, 289-300.

Scott, G. M., 1999, "Top priority management concerns about new product development." The Academy of Management Executive 13(3).

Shepherd, R. W., 1970, Theory of Cost and Production Functions. Princeton, Princeton University Press.

Silberglitt, R., A. Hove, et al., 2003, "Analysis of US energy scenarios - Meta-scenarios, pathways, and policy implications." Technological Forecasting and Social Change 70(4), 297-315.

Sueyoshi, T., 1998, "Privatization of Nippon telegraph and telephone: was it a good policy decision?" European Journal of Operational Research 107(1), 45-61.

Uri, N. D., 2001, "Changing productive efficiency in telecommunications in the United States." International Journal of Production Economics 72(2), 121-137.

Venkatesan, R. and V. Kumar, 2002, "A genetic algorithms approach to growth phase forecasting of wireless subscribers." International Journal of Forecasting 18(4), 625-646. 
Wang, T. Y. and S. C. Chien, 2006, "Forecasting innovation performance via neural networks a case of Taiwanese manufacturing industry." Technovation 26(5-6), 635-643

Watts, R. J. and A. L. Porter, 1997, "Innovation forecasting." Technological Forecasting and Social Change 56(1), 25-47.

Winebrake, J. J. and B. P. Creswick, 2003, "The future of hydrogen fueling systems for transportation - An application of perspective-based scenario analysis using the analytic hierarchy process." Technological Forecasting and Social Change 70(4), 359-384.

Yoo, S.-H. and H.-S. Moon, 2006, "An estimation of the future demand for portable Internet service in Korea." Technological forecasting and social change 73(5), 13.

\section{Appendix}

\begin{tabular}{|c|c|c|c|}
\hline Generation & Abbr. & Technology & Short Description \\
\hline \multirow{4}{*}{$1 G$} & AMPS & " Advanced Mobile Phone Service & $\begin{array}{l}\text { First standardized cellular service in } \\
\text { the world }\end{array}$ \\
\hline & NMT & Nordic Mobile Telephone 450/900 & $\begin{array}{l}\text { First fully-automatic cellular phone } \\
\text { system }\end{array}$ \\
\hline & TACS & Total Access Communication System & European version of AMPS \\
\hline & NAMPS & Narrowband Analog Mobile Phone Service & $\begin{array}{l}\text { Introduced as a solution to capacity } \\
\text { problems }\end{array}$ \\
\hline \multirow{5}{*}{$2 \mathrm{G}$} & D-AMPS & Digital Advanced Mobile Phone Service & Considered end of life \\
\hline & PDC & Personal Digital Cellular & Used in Japan, uses TDMA \\
\hline & CDMAone & Code Division Multiple Access & $\begin{array}{l}\text { First CDMA-based digital cellular } \\
\text { standard pioneered by Qualcomm }\end{array}$ \\
\hline & GSM & Global System for Mobile Communications & $\begin{array}{l}\text { Provides voice and circuit-switched } \\
\text { data services }\end{array}$ \\
\hline & iden & Integrated Digital Enhanced Network & Developed by Motorola \\
\hline $2.5 \mathrm{G}$ & CDMA2000 & Code Division Multiple Access 2000 & $\begin{array}{l}\text { A multiple access scheme for digital } \\
\text { radio to send voice, data, and } \\
\text { signaling data (such as a dialed } \\
\text { telephone number) between mobile } \\
\text { phones and cell sites. }\end{array}$ \\
\hline
\end{tabular}




\begin{tabular}{|c|c|c|c|}
\hline & $\begin{array}{l}\text { CDMA1x / } \\
3 \mathrm{x}\end{array}$ & Code Division Multiple Access 1x / 3x & $\begin{array}{l}\text { The designation "1xRTT" (1 times } \\
\text { Radio Transmission Technology) is to } \\
\text { identify the version of CDMA2000 } \\
\text { radio technology that operates in a } \\
\text { pair of } 1.25-\mathrm{MHz} \text { radio channels (one } \\
\text { times } 1.25 \mathrm{MHz} \text {, as opposed to three } \\
\text { times } 1.25 \mathrm{MHz} \text { in 3xRTT). }\end{array}$ \\
\hline & GPRS & General Packet Radio Service & Packet-switched data transmission \\
\hline & EDGE & Enhanced Data rates for GSM Evolution & $\begin{array}{l}\text { A radio based high-speed mobile data } \\
\text { standard }\end{array}$ \\
\hline \multirow{6}{*}{ 3G } & UMTS & $\begin{array}{l}\text { Universal Mobile Telecommunications } \\
\text { System }\end{array}$ & $\begin{array}{l}\text { Based on Internet Protocol (IP) } \\
\text { technology and supports packetized } \\
\text { voice and data at theoretical peak data } \\
\text { rates of up to } 2 \text { Mbps }\end{array}$ \\
\hline & HSDPA & High Speed Downlink Packet Access & data upgrade to UMTS/WCDMA \\
\hline & HSUPA & High Speed Uplink Packet Access & $\begin{array}{l}\text { data access protocol for mobile phone } \\
\text { networks with extremely high upload } \\
\text { speeds up to } 5.76 \mathrm{Mbit} / \mathrm{s} \text {. }\end{array}$ \\
\hline & $\begin{array}{l}\text { CDMA2000 } \\
\text { 1xEV-DO }\end{array}$ & $\begin{array}{l}\text { Code Division Multiple Access 1x } \\
\text { Evolution-Data Optimized }\end{array}$ & $\begin{array}{l}\text { is an evolution of CDMA2000 1x } \\
\text { with High Data Rate (HDR) capability } \\
\text { added }\end{array}$ \\
\hline & $\begin{array}{l}\text { CDMA2000 } \\
\text { 1xEV-DV }\end{array}$ & $\begin{array}{l}\text { Code Division Multiple Access 1x } \\
\text { Evolution-Data/Voice }\end{array}$ & $\begin{array}{l}\text { supports downlink (forward link) data } \\
\text { rates up to } 3.1 \mathrm{Mbit} / \mathrm{s} \text { and uplink } \\
\text { (reverse link) data rates of up to } 1.8 \\
\text { Mbit/s }\end{array}$ \\
\hline & OFDMA & $\begin{array}{l}\text { Orthogonal Frequency Division Multiple } \\
\text { Access }\end{array}$ & $\begin{array}{l}\text { alternative to combining OFDM with } \\
\text { time division multiple access } \\
\text { (TDMA) or time-domain statistical } \\
\text { multiplexing }\end{array}$ \\
\hline \multirow{3}{*}{$4 \mathrm{G}$} & MMAC & Multimedia Mobile Access Communication & 4G high-performance wireless system \\
\hline & ITS & Intelligent transport systems & $\begin{array}{l}\text { New transport system, which } \\
\text { comprises an advanced information } \\
\text { and telecommunications network for } \\
\text { users, roads, and vehicles. }\end{array}$ \\
\hline & HAPS & $\begin{array}{l}\text { High Altitude Stratospheric Platform Station } \\
\text { Systems }\end{array}$ & $\begin{array}{l}\text { Attractive for multimedia } \\
\text { communications, has the potential to } \\
\text { become the third communications } \\
\text { infrastructure after terrestrial and } \\
\text { satellite communications }\end{array}$ \\
\hline
\end{tabular}

